\title{
Postępowanie w zwyrodnieniu barwnikowym siatkówki - przegląd piśmiennictwa
}

\section{Retinitis pigmentosa - treatment modalities - review}

\author{
Kamila Krasodomska, Wojciech Lubiński ${ }^{凶}$ \\ Pomorski Uniwersytet Medyczny w Szczecinie, Katedra i Klinika Okulistyki, al. Powstańców Wlkp. 72, 70-111 Szczecin \\ $\triangle$ lubinski@pro.onet.pl
}

\begin{abstract}
Introduction: Progressive nature and lack of effective treatment of the retinitis pigmentosa (RP) leads to search for the new therapeutic methods to stop progression of the disease.

The aim of this study is to review the current treatment modalities that may influence progression of RP.

Materials and methods: Based on the results reported in the available literature, non-pharmacological and pharmacological investigation in RP has been reviewed.

Results: The results of numerous studies indicate that so far there is no cure for RP. However, there are methods that can slow down progression of the disease.
\end{abstract}

Conclusions: Therapeutic treatment of patients with RP should be focused on providing psychological care, education planning, assistance in making a decision about a future profession or having children. Ophthalmologists should provide partially sighted people with a complete list of available optical systems, as well as treat cataract and cysts macular changes often associated with RP.

Keywords: retinitis pigmentosa; pharmacological treatment; non-pharmacological treatment.

\begin{abstract}
ABSTRAKT
Wstęp: Postępujący przebieg zwyrodnienia barwnikowego (retinitis pigmentosa - RP) oraz brak skutecznego leczenia skłania do poszukiwania nowych metod terapeutycznych w celu zahamowania progresji choroby.

Celem niniejszej pracy była analiza aktualnych sposobów leczenia, które mogą wpływać na przebieg RP.

Materiały i metody: Na podstawie wyników opisanych w dostępnym piśmiennictwie dokonano przeglądu postępowania niefarmakologicznego i farmakologicznego w RP.

Wyniki: Nie ma dotychczas skutecznego leczenia RP, istnieją jednak metody mogące mieć wpływ na spowolnienie postępu choroby.
\end{abstract}

Wnioski: Postępowanie terapeutyczne u pacjentów z RP powinno być skoncentrowane na zapewnieniu opieki psychologicznej, zaplanowaniu kierunku edukacji, pomocy w wyborze przyszłego zawodu oraz podjęciu decyzji o posiadaniu potomstwa. Ze strony okulistycznej przedstawić należy przede wszystkim możliwości zastosowania systemów dla osób słabowidzących, a także leczenia współistniejących z RP zaćmy i zmian drobnotorbielowatych plamki.

Słowa kluczowe: zwyrodnienie barwnikowe siatkówki; postępowanie farmakologiczne; postępowanie niefarmakologiczne.

\section{WSTĘP}

Zwyrodnienie barwnikowe siatkówki (retinitis pigmentosa $\mathrm{RP})$ to schorzenie siatkówki z postępującą dystrofią systemu pręcikowego i czopkowego prowadzące do inwalidztwa wzrokowego. Jest najczęściej rozpoznawaną wrodzoną dystrofią siatkówki, której występowanie szacuje się na 1:4000 urodzeń $[1,2,3]$. Dziedziczenie RP może być autosomalnie dominujące (15-20\%), autosomalnie recesywne (20-25\%), sprzężone z chromosomem X (10-15\%) oraz sporadyczne (40-55\%). Naturalny przebieg RP jest najwolniejszy w formie autosomalnie dominującej, a najszybszy w formie sprzężonej z chromosomem X. Opisano ponad 40 mutacji genów związanych z RP [2].

Kryteria diagnostyczne obejmują postępujące zaburzenie widzenia zmierzchowego (nyktalopia) oraz zawężanie się obwodowego pola widzenia. Powszechnie znana klasyczna triada objawów na dnie oka to: zwężenie naczyń siatkówki, występowanie skupisk barwnika (tzw. komórek kostnych) oraz woskowo bladej tarczy nerwu wzrokowego. Rozpoznanie RP stawiane jest na podstawie wywiadu, oceny dna oka, badania pola widzenia wykazującego koncentryczne zawężenie oraz elektroretinogramu błyskowego (flash electroretinogram ERG), który pozwala obiektywnie określić stadium zaawansowania oraz postęp choroby. Wykazanie znaczącego upośledzenia funkcji systemu pręcikowego i czopkowego w badaniu ERG jest ponadto szczególnie przydatne do diagnostyki wczesnych stadiów choroby oraz postaci atypowych RP, tj. bez wspomnianych zmian na dnie oka $[1,4]$. Charakterystycznymi zmianami w ERG w przebiegu RP są redukcja pręcikowej i czopkowej fali b połączona ze znacznym wydłużeniem czasu kumulacji.

Ze względu na postępujący charakter choroby nieustannie poszukiwane są sposoby zatrzymania jej rozwoju oraz 
podejmowane próby zachowania użytecznego widzenia. Obecne działania terapeutyczne ograniczone są do leczenia współistniejących z RP chorób. Najczęstsze z nich to operacyjne usunięcie zaćmy (podtorebkowa tylna) oraz próby objawowego leczenia drobnotorbielowatych zmian plamki za pomocą inhibitorów anhydrazy węglanowej podawanych doustnie lub miejscowo we wczesnych fazach choroby $[4,5]$.

W celu spowolnienia naturalnego przebiegu RP w ostatnich latach wykorzystywano zarówno metody niefarmakologiczne, jak i farmakologiczne [6]. Działania niefarmakologiczne obejmowały ochronę przed światłem, dlatego pacjentom z RP zaleca się noszenie przyciemnionych szkieł w okularach, a w celu zmniejszenia światłowstrętu stosowanie szkieł z filtrami barwnymi żółtopomarańczowymi [4, 7], które dodatkowo poprawiają widzenie kontrastowe. Podejmowano również próby stosowania tlenoterapii hiperbarycznej (hyperbaric oxygen - HBO), aby spowolnić degenerację fotoreceptorów [6, 8].

Vingolo i wsp. [8] poddali 10-letniej obserwacji grupę 44 pacjentów z RP, u których stosowano HBO, oraz 44 pacjentów z RP otrzymujących suplementację witaminy A, stanowiących grupę kontrolną. Wykazano utrzymanie się 80\% wyjściowej ostrości wzroku u 63,3\% badanych oraz zachowanie pola widzenia u 31,6\% pacjentów z grupy badanej w porównaniu z odpowiednio $40 \%$ i 10,5\% u osób z grupy kontrolnej. Wartości średnie amplitud fali b ERG były także istotnie wyższe w grupie poddawanej HBO. Autorzy podkreślali możliwość ochrony fotoreceptorów siatkówki poprzez dostarczenie im tlenu niezbędnego do prawidłowych przemian rodopsyny. Jednak, jak zauważyli, nie jest to metoda pozwalająca wyleczyć RP, a jedynie czasowo poprawić funkcję fotoreceptorów siatkówki.

Niektórzy autorzy zwrócili także uwagę na konieczność zapewnienia pacjentom z RP pomocy psychologicznej z powodu postępującego obniżania ostrości wzroku, które prowadzi do ślepoty i związanych z nią następstw [4].

W postępowaniu farmakologicznym rozważano suplementację niektórych witamin, takich jak A i E $[9,10]$, kwasu dokozaheksagenowego (docosahexaenoic acid - DHA) [3, 10, 11, 12], luteiny $[13,14]$, kwasu walproinowego $[15,16]$, beta-karotenu [17], a także zastosowanie miejscowego podawania $0,2 \%$ winianu brimonidyny [18], wszczepianie wewnątrzgałkowych implantów [19] czy doustne przyjmowanie nilwadypiny [20]. Nadzieję wiąże się także z terapią genową [21, 22, 23] i transplantacją komórek macierzystych [21, 23, 24, 25, 26].

\section{SUPLEMENTACJA WITAMIN A, E ORAZ KWASU DOKOZAHEKSAENOWEGO}

Niestety wyniki randomizowanych, kontrolowanych badań oceniających zmiany w polu widzenia i ostrości wzroku oraz ERG u pacjentów z RP otrzymujących suplementację witamin A, E i DHA nie wykazały istotnego wpływu na zahamowanie postępów choroby [9, 10, 11, 12]. Berson i wsp. [9] badali 601 pacjentów z RP, których podzielili na 4 grupy: pierwsza otrzymywała $15000 \mathrm{IU} / \mathrm{d}$ witaminy A, druga 15000 IU/d witaminy A i 400 IU/d witaminy E, trzecia śladowe ilości witaminy
A i E, a czwarta 400 IU/d witaminy E. W obu grupach otrzymujących 15000 IU/d witaminy A autorzy zaobserwowali istotne spowolnienie pogorszenia funkcji bioelektrycznej siatkówki w przeciwieństwie do grup nieotrzymujących takiej dawki $(\mathrm{p}<0,01)$. Ponadto wśród pacjentów z najwyższymi wyjściowymi amplitudami w badaniu ERG, którzy przyjmowali 400 IU/d witaminy E, wykazano co najmniej 50\% redukcję amplitudy w porównaniu z pacjentami nieotrzymującymi takiej dawki $(\mathrm{p}<0,03)$. Podobne tendencje, chociaż nieistotne statystycznie, autorzy wykazali podczas analizy pola widzenia. Suplementacja witamin A i E nie przełożyła się na poprawę ostrości wzroku, która we wszystkich grupach pogarszała się ok. 1 literę rocznie.

Wyniki kolejnego badania Bersona i wsp. [10], oceniającego ostrość wzroku, pole widzenia oraz ERG (30 Hz) u 221 pacjentów z RP otrzymujących 15000 IU/d witaminy A i 1200 mg/d DHA lub 15000 IU/d witaminy A i placebo w okresie 4-letniej obserwacji, nie wykazały różnic istotnych statystycznie.

Kolejna analiza wyników tych samych autorów [11] u pacjentów z RP nieotrzymujących witaminy A przed włączeniem do badań, a rozpoczynających suplementację od łącznego stosowania $15000 \mathrm{IU} / \mathrm{d}$ witaminy A i $1200 \mathrm{mg} / \mathrm{d}$ DHA, ujawniła istotnie wolniejsze pogarszanie się pola widzenia $(\mathrm{p}<0,01)$ i redukcję amplitudy w ERG $(\mathrm{p}<0,03)$ w porównaniu z grupą otrzymującą $15000 \mathrm{IU} / \mathrm{d}$ witaminy A i placebo. Zmiany te utrzymywały się tylko przez pierwsze 2 lata badania. Efektu tego nie było w trzecim i czwartym roku obserwacji ani wśród pacjentów przyjmujących witaminę A przed włączeniem do badań. Wśród pacjentów przyjmujących witaminę A przed włączeniem do badań (15000 IU/d) suplementacja DHA nie przynosiła dodatkowych korzyści w analizowanych parametrach.

Wyniki badań ostrości wzroku, ERG i pola widzenia przeprowadzone przez Hoffmana i wsp. [12] u pacjentów z RP otrzymujących $400 \mathrm{mg} / \mathrm{d}$ DHA w porównaniu z grupą otrzymującą placebo nie wykazały istotnych różnic.

Zarówno krótko-, jak i długotrwałe stosowanie witaminy A u pacjentów z RP nie powodowało szkodliwego działania ogólnoustrojowego, nie przełożyło się jednak na istotną poprawę ostrości wzroku czy pola widzenia, zwłaszcza w okresie kilkuletniej obserwacji.

Mechanizm wpływu witaminy A oraz DHA na spowolnienie postępu RP nie został do końca poznany. Wiadomo, że znajdują się one w fotoreceptorach i odgrywają istotną rolę $\mathrm{w}$ ich prawidłowym funkcjonowaniu [27, 28].

Decydując się na długotrwałą suplementację witaminy A, która magazynowana jest głównie w wątrobie, należy pamiętać o regularnym oznaczaniu poziomu retinolu, triglicerydów oraz enzymów wątrobowych (aminotransferaza asparaginowa, aminotransferaza alaninowa, fosfataza alkaliczna) we krwi. Konieczne jest także - ze względu na zwiększone ryzyko wystąpienia osteoporozy - monitorowanie gęstości kości. Podawanie witaminy A nie jest zalecane osobom poniżej 18. r.ż., kobietom w wieku rozrodczym, będącym w ciąży lub ją planującym - z uwagi na swe potencjalne teratogenne działanie, a także pacjentom z RP, u których wykryto mutację 
w genie $A B C A 4$ [4]. Pacjentom z RP nie zaleca się również suplementacji witaminy E [9].

\section{SUPLEMENTACJA LUTEINY}

Wyniki badania Bahrami i wsp. [13] u 34 pacjentów z RP ujawniły korzystny wpływ na zachowanie pola widzenia po suplementacji luteiny przez okres 24 tyg. (dawka początkowa $10 \mathrm{mg} / \mathrm{d}$ przez pierwsze 12 tyg., następnie $30 \mathrm{mg} / \mathrm{d}$ przez następne 12 tyg.). Hipotezą tłumaczącą potencjalne korzyści wynikające ze stosowania luteiny przez pacjentów z RP jest jej obecność $w$ fotoreceptorach oraz możliwość poprawy ostrości wzroku i pola widzenia [29]. Analiza wyników badań Bersona i wsp. [14] obejmująca 225 pacjentów z RP niepalących papierosów, którzy otrzymywali luteinę w dawce $12 \mathrm{mg} / \mathrm{d}$ przez okres 4 lat i dodatkowo przyjmujących witaminę A w dawce $15000 \mathrm{UI} / \mathrm{d}$, wykazała wolniejszą utratę pola widzenia jedynie na średnim obwodzie. Autorzy ci nie wykazali jednak różnic statystycznie istotnych w poprawie ostrości wzroku, w amplitudach ERG ani w zachowaniu pola widzenia pomiędzy grupą otrzymującą luteinę z witaminą A a grupą kontrolną otrzymującą placebo z witaminą A. Ponadto na uwagę zasługuje fakt, że zwiększanie poziomu luteiny w surowicy nie przyniosło dodatkowych korzyści.

\section{SUPLEMENTACJA KWASU WALPROINOWEGO}

Kwas walproinowy jest powszechnie stosowanym lekiem o działaniu przeciwdrgawkowym. W ostatnich latach ukazały się doniesienia sugerujące potencjalne właściwości kwasu walproinowego stymulujące komórki glejowe do różnicowania się w komórki podobne do fotoreceptorów [30, 31]. Podawanie kwasu walproinowego w dawce $500 \mathrm{mg} / \mathrm{d}$ (znacznie mniejszej niż dawka stosowana w leczeniu przeciwdrgawkowym) 15 pacjentom z RP podczas jednorocznej obserwacji spowodowało istotną statystycznie poprawę ostrości wzroku $(\mathrm{p}<0,01)$ oraz poprawę wyników badań wieloogniskowego elektroretinogramu - mfERG $(\mathrm{p}<0,01)$ [15]. Iraha i wsp. [16] 29 pacjentom z RP podawali $400 \mathrm{mg} / \mathrm{d}$ kwasu walproinowego przez 6 miesięcy, a następnie suplementację tę wstrzymali na 6 kolejnych miesięcy. Stwierdzili oni statystycznie istotną poprawę ostrości wzroku i pola widzenia podczas przyjmowania kwasu walproinowego w porównaniu z okresem zaprzestania jego suplementacji. Nie zaobserwowali działań niepożądanych. Inni autorzy, oceniając retrospektywne wyniki pacjentów z RP przyjmujących kwas walproinowy, stwierdzili pogarszanie się ostrości wzroku, zawężanie pola widzenia oraz występowanie działań niepożądanych [32].

\section{SUPLEMENTACJA BETA-KAROTENU}

Prekursor retinalu - naturalnego metabolitu witaminy A 9-cis beta-karoten bogato występuje w algach Dunaliella bardawil [33]. Doustne podawanie $300 \mathrm{mg} / \mathrm{d}$ alg Dunaliella bardawil 29 pacjentom z RP w okresie 3-miesięcznej obserwacji skutkowało poprawą funkcji bioelektrycznej siatkówki, która objawiała się zwiększeniem amplitudy fali b w ERG, nie poprawiło natomiast istotnie ani ostrości wzroku, ani pola widzenia w porównaniu z grupą otrzymującą placebo [17]. Autorzy podkreślali możliwość doustnego stosowania 9-cis beta-karotenu, który może zostać przekształcony do 9-cis retinalu, będącego częścią rodopsyny, jako wspomagającego inne postępowanie terapeutyczne u pacjentów z RP.

\section{MIEJSCOWE STOSOWANIE KROPLI 0,2\% BRYMONIDYNY}

Celem zastosowania neuroprotekcyjnego działania brymonidyny była próba spowolnienia lub zahamowania śmierci fotoreceptorów w obrębie siatkówki u pacjentów z RP. W randomizowanym, podwójnie ślepym badaniu wśród 17 pacjentów z RP stosujących brymonidynę miejscowo przez okres 24-36 miesięcy (średnio 29) nie zaobserwowano poprawy pola widzenia, ostrości wzroku ani czułości kontrastowej w porównaniu ze stosowaniem sztucznych łez [18].

\section{WEWNĄTRZGAŁKOWY IMPLANT CNTF}

Wewnątrzgałkowy implant CNTF (ciliary neurotrophic factor) jest neurotroficznym czynnikiem produkowanym przez komórki nerwowe, który - jak wykazano w badaniach na zwierzętach - może pomóc w zachowaniu pręcików i czopków [34]. Birch i wsp. [19] u 133 pacjentów z RP wszczepiali wewnątrzgałkowe implanty CNTF (uwalniające niską - $5 \mathrm{ng} / \mathrm{d}$ lub wysoką $20 \mathrm{ng} / \mathrm{d}$ dawkę neurotroficznego czynnika) do losowo wybranego oka na okres 12 lub 24 miesięcy. Nie zaobserwowali oni jednak statystycznej poprawy widzenia lub poprawy parametrów ERG, a wysoka dawka CNTF dodatkowo istotnie pogarszała pole widzenia.

\section{NILWADYPINA STOSOWANA DOUSTNIE}

Wyniki badań Portera-Cailliau i wsp. [35] ujawniły, że zwyrodnienie fotoreceptorów w RP zachodzi na drodze apoptozy, podczas której w komórkach wzrasta poziom jonów wapnia [36]. Stąd hipoteza zakładająca, że zastosowanie blokerów kanałów wapniowych może przyczynić się do ochrony fotoreceptorów przed apoptozą. Przyjmowanie nilwadypiny blokera kanałów wapniowych penetrującego barierę krewsiatkówka - w dawce $4 \mathrm{mg} / \mathrm{d}$ przez pacjentów z RP w okresie 30-66 miesięcy istotnie spowolniło zwężanie pola widzenia w porównaniu z grupą kontrolną otrzymującą tokoferol (300 mg/d) lub helenien (15 mg/d), czy też pozostającą bez leczenia [20]. Stosowanie nilwadypiny u pacjentów z RP może się okazać pomocne jako terapia wspomagająca inne metody leczenia tego schorzenia. 


\section{TERAPIA GENOWA}

W terapii genowej wykorzystuje się wprowadzenie prawidłowego DNA za pomocą zmodyfikowanych wektorów wirusowych (obecnie podejmowane są także próby zastosowania cząstek niewirusowych) do komórek pacjenta. W okulistyce stosuje się iniekcje podsiatkówkowe powodujące jej przejściowe odwarstwienie lub iniekcje doszklistkowe [23]. Ideą zastosowania takiego leczenia jest zmodyfikowanie i naprawienie mutacji nieprawidłowych fragmentów DNA. W ostatnich latach pojawiły się wyniki badań klinicznych na temat zastosowania terapii genowej w leczeniu dziedzicznych chorób siatkówki, takich jak ślepota Lebera czy choroidremia [21, 22, 37]. Dotychczasowe wyniki zastosowania terapii genowej z użyciem wektora wirusowego AAV (adeno-associated virus) połączonego z genem RPE65 są obiecujące [22, 23]. Bainbridge i wsp. [22] ujawnili poprawę czułości kontrastowej u 6 pacjentów utrzymującą się przez 3 lata badań - największą w okresie 6-12 miesięcy, a następnie jej redukcję, nie zaobserwowali poprawy widzenia ani obiektywnej poprawy funkcji bioelektrycznej siatkówki w ERG. Wynik badań Ghazi i wsp. [38] ujawniły przejściową poprawę widzenia u połowy z 6 pacjentów z RP, która u 2 osób nie utrzymała się do końca trwania 2-letniej obserwacji.

Wyniki badań zastosowania terapii genowej w leczeniu dystrofii siatkówkowych sugerują jej możliwą skuteczność we wczesnych stadiach choroby, czyli metoda ta może być efektywna u pacjentów, u których nie doszło jeszcze do zniszczenia znaczącej liczby fotoreceptorów.

\section{KOMÓRKI MACIERZYSTE}

W ostatnich latach nadzieja na skuteczne leczenie RP wiązana jest z komórkami macierzystymi, a zwłaszcza z mezenchymalnymi komórkami macierzystymi szpiku kostnego (bone marrow-derived mesenchymal stem cells) - samoodnawiającymi się i mającymi zdolność różnicowania się w wiele linii komórkowych, w tym także w siatkówkowe komórki podobne do fotoreceptrów [24, 39], a także z indukowanymi pluripotencjalnymi komórkami macierzystymi (induced pluripotent stem cells) - sztucznie uzyskanymi od pacjentów z RP, mogącymi różnicować się w komórki fotoreceptorów [39, 40, 41]. Mechanizm działania terapii komórkami macierzystymi w przypadku dziedzicznych chorób siatkówki opiera się na: 1) zastąpieniu zdegenerowanych komórek siatkówki przez prawidłowe komórki szpiku; 2) zapewnieniu przeżycia fotoreceptorów siatkówki poprzez czynniki troficzne wydzielane przez komórki macierzyste; 3) ochronie czopków i naczyń siatkówki poprzez zwiększenie aktywności antyapoptotycznych genów przez komórki macierzyste; 4) promowaniu nowych połączeń synaptycznych [24]. W przeciwieństwie do terapii genowej, w której dochodzi do naprawy zmutowanych genów w żyjących komórkach, terapia komórkami macierzystymi może zastąpić obumarłe komórki. Wyniki badań na zwierzętach oceniające bezpieczeństwo, tolerancję i skuteczność doszklistkowego podania komórek macierzystych w leczeniu RP są zachęcające, dlatego rozpoczęto także badania kliniczne. Siqueira i wsp. [25] w I fazie badań klinicznych po podaniu jednej iniekcji komórek macierzystych 5 pacjentom - 3 z RP oraz 2 z dystrofią czopkowo-pręcikową - nie zauważyli efektów ubocznych w okresie 10-miesięcznej obserwacji. U 4 pacjentów uzyskano poprawę widzenia; nie wykazano zmian w polu widzenia ani w ERG. Wyniki kolejnego badania [26] u 20 pacjentów z RP, którzy otrzymali doszklistkową iniekcję komórek macierzystych, ujawniły istotną poprawę jakości życia przez pierwsze 3 miesiące od podania. Poprawa nie utrzymała się jednak do końca trwania obserwacji, tj. przez 12 miesięcy.

Uważa się, że przyszłość stosowania komórek macierzystych w leczeniu dystrofii siatkówkowych będzie zależała nie tylko od zdolności tych komórek do przekształcania się w fotoreceptory, lecz także od możliwości wykształcenia odpowiednich połączeń synaptycznych we wzrokowej drodze widzenia [23].

\section{WNIOSKI}

Przytoczone w niniejszej pracy wyniki badań pokazują, że obecnie nie ma przyczynowego leczenia RP. Postępowanie z pacjentem chorującym na RP powinno obejmować przede wszystkim określenie typu dziedziczenia i poinformowanie o naturalnym przebiegu choroby, a w razie konieczności zapewnienie opieki psychologicznej - zarówno dla osób dotkniętych chorobą, jak i ich najbliższych. Jest to szczególnie istotne dla osób młodych, stojących przed wyborem kierunku edukacji i zawodu oraz decyzją o posiadaniu potomstwa.

Warto także poinformować o możliwościach doboru systemów optycznych dla osób słabowidzących, takich jak np. lupy z podświetleniem lub bez podświetlenia, okulary lupowe/lornetowe czy specjalistyczne oprogramowanie umożliwiające korzystanie z telefonów komórkowych i komputerów.

Ze strony okulistycznej należy umożliwić pacjentom z RP leczenie często współistniejących schorzeń oczu, tj. zaćmy oraz drobnotorbielowatych zmian plamki, które pogarszają ostrość i jakość widzenia. W leczeniu objawowym rozważyć można suplementację: 1) witaminą A bądź jej prekursorami; 2) nilwadypiną; 3) stosowanie tlenoterapii hiperbarycznej - zwłaszcza w początkowych fazach choroby, gdy nie doszło jeszcze do znacznego uszkodzenia fotoreceptorów. Wykorzystanie terapii genowej czy komórek macierzystych wymaga jeszcze dalszych badań i potwierdzenia ich efektu na większej liczbie pacjentów.

Powinno się także przestrzec pacjentów z RP przed „leczeniem" u osób niezwiązanych z medycyną i proponujących innowacyjne metody terapeutyczne, gdyż ich celem jest jedynie chęć zysku, a nie rzetelna pomoc.

\section{PIŚMIENNICTWO}

1. Haim M. Epidemiology of retinitis pigmentosa in Denmark. Acta Ophthalmol Scand Suppl 2002;233:1-34.

2. Chang S, Vaccarella L, Olatunji S, Cebulla C, Christoforidis J. Diagnostic challenges in retinitis pigmentosa: genotypic multiplicity and 
phenotypic variability. Curr Genomics 2011;12(4):267-75. doi: $10.2174 / 138920211795860116$

3. Rayapudi S, Schwartz SG, Wang X, Chavis P. Vitamin A and fish oils for retinitis pigmentosa. Cochrane Database Syst Rev 2013;12:CD008428. doi: 10.1002/14651858.CD008428.pub2.

4. Hamel C. Retinitis pigmentosa. Orphanet J Rare Dis 2006;1:40. doi: 10.1186/1750-1172-1-40.

5. Fishman GA, Apushkin MA. Continued use of dorzolamide for the treatment of cystoid macular oedema in patients with retinitis pigmentosa. Br J Ophthalmol 2007;91(6):743-5. doi: 10.1136/bjo.2006.107466.

6. Sacchetti M, Mantelli F, Lambiase A, Mastropasqua A, Merlo D, Bonini S. Systematic review of randomised clinical trials on topical ciclosporin A for the treatment of dry eye disease. Br J Ophthalmol 2014;98(8):1016-22. doi: 10.1136/bjophthalmol-2013-304072.

7. Wang M, Lam TT, Tso MO, Naash MI. Expression of a mutant opsin gene increases the susceptibility of the retina to light damage. Vis Neurosci 1997;14(1):55-62.

8. Vingolo EM, Rocco M, Grenga P, Salvatore S, Pelaia P. Slowing the degenerative process, long lasting effect of hyperbaric oxygen therapy in retinitis pigmentosa. Graefes Arch Clin Exp Ophthalmol 2008;246(1):93-8. doi: 10.1007/s00417-007-0652-z

9. Berson EL, Rosner B, Sandberg MA, Hayes KC, Nicholson BW, Weigel-DiFranco C, et al. A randomized trial of vitamin A and vitamin E supplementation for retinitis pigmentosa. Arch Ophthalmol 1993;111(6):761-72.

10. Berson EL, Rosner B, Sandberg MA, Weigel-DiFranco C, Moser A, Brockhurst RJ, et al. Clinical trial of docosahexaenoic acid in patients with retinitis pigmentosa receiving vitamin A treatment. Arch Ophthalmol 2004;122(9):1297-305. doi: 10.1001/archopht.122.9.1297.

11. Berson EL, Rosner B, Sandberg MA, Weigel-DiFranco C, Moser A, Brockhurst RJ, et al. Further evaluation of docosahexaenoic acid in patients with retinitis pigmentosa receiving vitamin A treatment: subgroup analyses. Arch Ophthalmol 2004;122(9):1306-14. doi: 10.1001/archopht. 122.9.1306.

12. Hoffman DR, Locke KG, Wheaton DH, Fish GE, Spencer R, Birch DG. A randomized, placebo-controlled clinical trial of docosahexaenoic acid supplementation for X-linked retinitis pigmentosa. Am J Ophthalmol 2004;137(4):704-18. doi: 10.1016/j.ajo.2003.10.045.

13. Bahrami H, Melia M, Dagnelie G. Lutein supplementation in retinitis pigmentosa: PC-based vision assessment in a randomized double-masked placebo-controlled clinical trial [NCT00029289]. BMC Ophthalmol 2006;6:23. doi: 10.1186/1471-2415-6-23.

14. Berson EL, Rosner B, Sandberg MA, Weigel-DiFranco C, Brockhurst RJ, Hayes KC, et al. Clinical trial of lutein in patients with retinitis pigmentosa receiving vitamin A. Arch Ophthalmol 2010;128(4):403-11. doi: 10.1001/ archophthalmol.2010.32.

15. Kumar A, Midha N, Gogia V, Gupta S, Sehra S, Choha A. Efficacy of oral valproic acid in patients with retinitis pigmentosa. J Ocul Pharmacol Ther 2014;30(7):580-6. doi: 10.1089/jop.2013.0166.

16. Iraha S, Hirami Y, Ota S, Sunagawa GA, Mandai M, Tanihara H. Efficacy of valproic acid for retinitis pigmentosa patients: a pilot study. Clin Ophthalmol 2016;10:1375-84. doi: 10.2147/OPTH.S109995.

17. Rotenstreich Y, Belkin M, Sadetzki S, Chetrit A, Ferman-Attar G, Sher I, et al. Treatment with 9-cis $\beta$-carotene-rich powder in patients with retinitis pigmentosa: a randomized crossover trial. JAMA Ophthalmol 2013;131(8):985-92. doi: 10.1001/jamaophthalmol.2013.147.

18. Merin S, Obolensky A, Farber MD, Chowers I. A pilot study of topical treatment with an alpha2-agonist in patients with retinal dystrophies. J Ocul Pharmacol Ther 2008;24(1):80-6. doi: 10.1089/jop.2007.0022.

19. Birch DG, Weleber RG, Duncan JL, Jaffe GJ, Tao W. Randomized trial of ciliary neurotrophic factor delivered by encapsulated cell intraocular implants for retinitis pigmentosa. Am J Ophthalmol 2013;156(2):283-92. doi: 10.1016/j.ajo.2013.03.021.

20. Nakazawa M, Ohguro H, Takeuchi K, Miyagawa Y, Ito T, Metoki T. Effect of nilvadipine on central visual field in retinitis pigmentosa: a 30-month clinical trial. Ophthalmologica 2011;225(2):120-6. doi: 10.1159/000320500.
21. Lin MK, Tsai YT, Tsang SH. Emerging treatments for retinitis pigmentosa: Genes and stem cells, as well as new electronic and medical therapies, are gaining ground. Retin Physician 2015;12:52-70.

22. Bainbridge JW, Mehat MS, Sundaram V, Robbie SJ, Barker SE, Ripamonti C, et al. Long-term effect of gene therapy on Leber's congenital amaurosis. N Engl J Med 2015;372(20):1887-97. doi: 10.1056/NEJMoa1414221.

23. Sengillo JD, Justus S, Tsai YT, Cabral T, Tsang SH. Gene and cell-based therapies for inherited retinal disorders: An update. Am J Med Genet C Semin Med Genet 2016;172(4):349-366. doi: 10.1002/ajmg.c.31534.

24. He Y, Zhang Y, Liu X, Ghazaryan E, Li Y, Xie J, et al. Recent advances of stem cell therapy for retinitis pigmentosa. Int J Mol Sci 2014;15(8):14456-74. doi: 10.3390/ijms150814456.

25. Siqueira RC, Messias A, Voltarelli JC, Scott IU, Jorge R. Intravitreal injection of autologous bone marrow-derived mononuclear cells for hereditary retinal dystrophy: a phase I trial. Retina 2011;31(6):1207-14. doi: 10.1097/IAE.0b013e3181f9c242.

26. Siqueira RC, Messias A, Messias K, Arcieri RS, Ruiz MA, Souza NF, et al. Quality of life in patients with retinitis pigmentosa submitted to intravitreal use of bone marrow-derived stem cells (Reticell-clinical trial). Stem Cell Res Ther 2015;6:29. doi: 10.1186/s13287-015-0020-6.

27. Berson EL. Nutrition and retinal degenerations: Vitamin A, taurine, ornithine, and phytanic acid. Retina 1982;2(4):236-55.

28. Chen Y, Houghton LA, Brenna JT, Noy N. Docosahexaenoic acid modulates the interactions of the interphotoreceptor retinoid-binding protein with 11-cis-retinal. J Biol Chem 1996;271(34):20507-15.

29. Sommerburg OG, Siems WG, Hurst JS, Lewis JW, Kliger DS, van Kuijk FJ. Lutein and zeaxanthin are associated with photoreceptors in the human retina. Curr Eye Res 1999;19(6):491-5.

30. Kubota A, Nishida K, Nakashima K, Tano Y. Conversion of mammalian Müller glial cells into a neuronal lineage by in vitro aggregate-culture. Biochem Biophys Res Commun 2006;351(2):514-20. doi: 10.1016/j.bbrc.2006.10.072.

31. Göttlicher M, Minucci S, Zhu P, Krämer OH, Schimpf A, Giavara S. Valproic acid defines a novel class of HDAC inhibitors inducing differentiation of transformed cells. EMBO J 2001;20(24):6969-78. doi: 10.1093/ emboj/20.24.6969.

32. Bhalla S, Joshi D, Bhullar S, Kasuga D, Park Y, Kay CN. Long-term follow-up for efficacy and safety of treatment of retinitis pigmentosa with valproic acid. J Ophthalmol 2013;97(7):895-9. doi: 10.1136/bjophthalmol-2013-303084.

33. Ben-Amotz A, Lers A, Avron M. Stereoisomers of beta-carotene and phytoene in the Alga Dunaliella bardawil. Plant Physiol 1988;86(4):1286-91.

34. Wen R, Tao W, Li Y, Sieving PA. CNTF and retina. Prog Retin Eye Res 2012;31(2):136-51. doi: 10.1016/j.preteyeres.2011.11.005.

35. Portera-Cailliau C, Sung CH, Nathans J, Adler R. Apoptotic photoreceptor cell death in mouse models of retinitis pigmentosa. Proc Natl Acad Sci U S A 1994;91(3):974-8.

36. Nicotera P, Orrenius S. The role of calcium in apoptosis. Cell Calcium 1998;23(2-3):173-80.

37. Maguire AM, Simonelli F, Pierce EA, Pugh EN Jr, Mingozzi F, Bennicelli J, et al. Safety and efficacy of gene transfer for Leber's congenital amaurosis. N Engl J Med 2008;358(21):2240-8. doi: 10.1056/NEJMoa0802315.

38. Ghazi NG, Abboud EB, Nowilaty SR, Alkuraya H, Alhommadi A, Cai H, et al. Treatment of retinitis pigmentosa due to MERTK mutations by ocular subretinal injection of adeno-associated virus gene vector: results of a phase I trial. Hum Genet 2016;135(3):327-43. doi: 10.1007/s00439-016-1637-y.

39. Kicic A, Shen WY, Wilson AS, Constable IJ, Robertson T, Rakoczy PE. Differentiation of marrow stromal cells into photoreceptors in the rat eye. J Neurosci 2003;23(21):7742-9.

40. Jin ZB, Okamoto S, Xiang P, Takahashi M. Integration-free induced pluripotent stem cells derived from retinitis pigmentosa patient for disease modeling. Stem Cell Trans Med 2012;1(6):503-9. doi: 10.5966/sctm.2012-0005.

41. Tucker BA, Mullins RF, Streb LM, Anfinson K, Eyestone ME, Kaalberg E, et al. Patient-specific iPSC-derived photoreceptor precursor cells as a means to investigate retinitis pigmentosa. Elife 2013;2:e00824. doi: 10.7554/eLife.00824. 